\title{
Who Said No? Voting Behaviour in the 2016 Bolivian Constitutional ReferenduM*
}

\author{
¿Quién dijo no? Comportamiento electoral en el referéndum \\ constitucional de Bolivia en 2016
}

\section{MAXIME BLANCHARD}

McGill University, Canada

\begin{abstract}
What explains the sudden rise and fall of Latin America's leftist governments during the $21^{\text {st }}$ century? Two competing interpretations have been put forward: either citizens vote positionally or retrospectively. This paper aims to shed light on this debate by analyzing the 2016 constitutional referendum in Bolivia. The results of our investigation of voting behaviour are most supportive of a retrospective voting interpretation. Dissatisfaction with the state of democracy in Bolivia and having experienced regional protests are both shown to be the strongest predictors of a "No" vote. The results support the claim that valence issues most significantly determine voting behaviour in new democracies, yet they also suggest that retrospective assessments of governmental performance extend further than mere economic conditions.
\end{abstract}

Keywords: Latin American left, Positional Voting, Retrospective Voting, Bolivia, Constitutional Referendum.

\begin{abstract}
RESUMEN
¿Qué explica el ascenso y caída de los gobiernos de izquierda de América Latina durante el siglo XXI? ? Se han presentado dos interpretaciones: los ciudadanos suelen votar de manera posicional o retrospectiva. El presente artículo pretende alimentar este debate téorico mediante el análisis del referéndum constitucional de 2016 en Bolivia. Los resultados de esta investigación sobre el comportamiento de los votantes muestran una tendencia favorable a la interpretación del voto retrospectivo, apoyando la afirmación de que los llamados valence issues tienen un impacto significativo sobre el comportamiento electoral en las nuevas democracias. Al mismo tiempo, los resultados también sugieren que el análisis retrospectivo del desempeño gubernamental superan el simple impacto de las condiciones económicas.
\end{abstract}

Palabras clave: izquierda latinoamericana, voto posicional, vote retrospectivo, Bolivia, referéndum constitucional. 


\section{INTRODUCTION}

What explains the sudden rise and fall of Latin America's leftist presidents during the $21^{\text {st }}$ century? While the 2000s have seen the sudden reemergence and rise to power of the Latin American left, the following decade has been marked by the reverse trend, as all but a few of Latin America's leftist presidents have lost power in sequence. The interpretations of such events have mostly debated whether transitions from rightist to leftist governments (and vice versa) emerge out of popular dissatisfaction with incumbent performance or are rather related to voters expressing their policy preferences.

Much has been written about the reemergence of the Latin American left, but its contemporary demise has yet to gather similar attention. However, this latter turn of events constitutes a new opportunity to study the determinants of the region's alternation between leftist and rightist presidents. Investigating this trend allows us to contribute to the broader debate on the capacity of voters to display sophistication through positional voting, as opposed to mere retrospective voting. This paper proposes to make a first step in that direction by looking at Evo Morales' failed referendum bid in 2016, in which the Bolivian electorate rejected a proposed constitutional amendment which would have allowed their president to seek indefinite re-election.

Two main interpretations have emerged as to why would Latin American voters suddenly quit supporting their leftist presidents, and both can be understood as an extension of the debate regarding the reasons why they initially supported such candidates. Simply put, some scholars and commentators alike believe the left's demise to be the result of voters expressing their dissatisfaction with the performance of their incumbent, whereas others believe voters to have expressed a sincere preference for rightist policy orientations. Once again, it comes down to whether Latin America's alternation between leftist and rightist governments is the product of retrospective or positional voting.

The aim of this article is to contribute to shed light on this debate through an analysis of voting behaviour in the 2016 constitutional referendum in Bolivia, during which the possibility of permitting Evo Morales to remove the constitutional term limit and seek re-election was at stake. The objective is to uncover the individual-level determinants of vote choice during the referendum to better understand why did Bolivian voters, as many other Latin American citizens, turned their back on their leftist president. To do so, the analysis relies on public opinion data taken from the 2016-17 Latin American Public Opinion Project (LAPOP). Using attitudinal variables related to policy preferences and (dis)satisfaction with the incumbent's performance, the empirical analysis tests the positional and retrospective voting interpretations. The results are most supportive of the latter hypothesis, as they indicate that dissatisfaction with the protection of civil rights is strongly associated with the expression of a "No" vote. 


\section{ELECTORAL BEHAVIOUR AND LATIN AMERICA'S LEFTIST DECADE}

The beginning of the left turn in Latin America is usually identified as the 1998 Venezuelan presidential election which brought Hugo Chávez to power. A flurry of leftist leaders followed Chávez's path in succeeding to be elected president during the first decade of the $21^{\text {st }}$ century, usually by proposing deep economic reforms that were expected to alleviate socioeconomic inequalities. Two distinct interpretations of voting behaviour during this leftist regional turn have been offered. A first one presents this phenomenon as the result of voters giving their government a leftist mandate, although debates remain on how radical were voters' demands (Baker \& Greene, 2011; Levitsky \& Roberts, 2011). According to this interpretation, Latin American voters would have made a positional vote, wittingly offering their support to left-leaning parties and candidates to dismantle the neoliberal policies of their predecessors (Weyland, 2011).

A second group of scholars offers a more straightforward interpretation which better suits the usual assumptions regarding voting behaviour in the developing world. They claim the left turn to be mainly the result of voters being unsatisfied with the state of their national economy, which led them to withdraw their support to rightist incumbents and turn themselves toward the leftist opposition (Murillo, Oliveros, \& Vaishnav, 2010; Remmer, 2012). Further supporting their claim is public opinion evidence indicating that Latin American voters have not adopted significantly more left-leaning stances during the period (Arnold \& Samuels, 2011). Hence, in the absence of a reorientation of voters' policy preferences, positional voting appears unlikely to successfully account for the left's uprising. The main point of agreement regarding the two diverging interpretations lies in the centrality of economic issues in the process, as both groups of scholars put them at the core of their argument.

A decade more or less after the upsurge of the political left in Latin America, the reverse trend started to appear, as many left-leaning presidents lost power in sequence, either through electoral defeats or impeachment procedures (Paraguay and Brazil). Even among leftist governments still in office, two have been facing social unrest (Venezuela and Nicaragua), and another one has re-centered itself (Ecuador). Latin America's left turn thus appears to be dying off as rapidly and unexpectedly as it came to life.

The similarities between the upsurge and the downfall of the left turn are plentiful and very significant. In both cases, a large number of countries from the same region elected new presidents from the same side of the political spectrum. Those countries share many economic, cultural, and social similarities. The region also faced generalized economic hardships which hindered the capacity of governments to fulfill voters' expectations both at the time of the upsurge and the downfall of leftist governments (Murillo, Oliveros, \& Vaishnav, 2011). Those political swings are thus not simple and direct to explain from a micro-level perspective. They hint at a shift in the policy preferences of voters 
which would have emerged from a shared experience, as replacement governments across the region all favored a rupture with their predecessors' economic and social policies. Yet, as mentioned above, no evidence of such shift has been found among public opinion data analyses. Moreover, scholars of Latin American electoral behaviour have usually claimed positional issue preferences to be weak predictors of vote choice (Stokes, 2001; Arnold \& Samuels, 2011; Nadeau et al., 2017). In a panel study of the 2000 Mexican election, McCann \& Lawson (2003) find that voters' issue preferences varied substantially in only a six months period. Such instability in policy preferences contributes to foster doubt regarding their capacity to account for voting behaviour in the region.

Yet, political preferences have been demonstrated to be a complex matter to assess (Achen, 1975; Ansolabehere et al., 2008). Baker \& Greene (2015) accordingly claim the impact of positional issue preferences on Latin American elections to have been significantly underestimated because of inadequate measurement techniques. It thus appears unclear if the left turn and its subsequent collapse have been the product of a change in voters' policy preferences that scholars have failed to properly measure, or if both events were the product of mere dissatisfaction with incumbent performance leading to democratic alternation.

Taking into account the economic conditions prevailing in the region during both periods lends credibility to the possibility that voters' dissatisfaction with the performance of their government led them to seek alternation. The upsurge and the downfall of the left were associated with economic hardships, with the interlude between the two periods marked by economic stability. It thus appears reasonable to believe that retrospective economic perceptions rather than policy preferences have driven the rise and fall of leftist governments across the region. As Murillo et al. (2010) point out, this would imply that the left turn merely constituted democratic alternation, with unsatisfied voters punishing their rightist incumbent. The main issue with such interpretation lies in its incapacity to account for the fact that voters did not appoint any new president, but rather appointed leftist candidates sharing the objective of lowering socioeconomic inequalities (Weyland, 2011). Hence, the debate remains open not only regarding the causes of Latin America's political swings, but also regarding the impact of voters' policy preferences on voting behaviour in the region.

\section{THE BOLIVIAN CASE}

Among all the leaders of Latin America's left wave, Evo Morales is one of those that have drawn the most attention. His first election as president occurred in 2005, after running on an anti-neoliberalism platform which heavily criticized economic reforms established during the 1990s and early 2000s (Madrid, 2011). On many levels, the election of Morales carried significant regional implications. He was the first self-proclaimed indigenous political candidate to be elected president of a Latin American country, he was previously directly in- 
volved in social movements, and his rise to power happened exactly as the left was taking the Latin American subcontinent by storm. Moreover, he was one of the most radical leaders of the left turn, promoting a " $21^{\text {st }}$ century socialism" which essentially culminated in an increased state intervention in the economy and the creation of various wealth redistribution policies (Molina, 2010).

Although a very polarizing figure, Morales' popularity is undeniable. After being first elected in 2005, he was re-elected in 2009 and 2014, successfully obtaining an absolute majority of the vote in the first round of all three elections, a very rare feat in Latin America, let alone three consecutive times. Yet, after his win in the 2014 presidential election, the Bolivian constitution prohibited Morales from seeking another term in office. The incumbent therefore decided to hold a referendum asking citizens to allow him to remove the constitutional presidential term limit, which would have made possible for him to seek indefinite re-election.

The referendum question formally referred to the removal of the term limit embedded in the constitution, yet most of the debate during the campaign focused on Morales and the possibility for him - rather than for any Bolivian president - to seek indefinite re-election. Little attention was paid to the constitutional amendment per se and few debates focused on the type of institutional constraints that would be desirable to impose on the executive power. The referendum can therefore be understood as a plebiscite where the main issue under consideration was whether Evo Morales deserved or not to be re-elected. Using David Altman's terminology, the Bolivian referendum was a top-down mechanism of direct democracy intended to allow Morales to obtain the popular legitimacy to bypass a fundamental constitutional rule (Altman, 2011). Such legitimization tools have been increasingly used by Latin American presidents during the last decades, especially among those facing little intraparty competition (Kouba, 2016), yet their outcome have not been systematically favorable to the presidents using them (Altman, 2010). Nevertheless, such plebiscites tend to be highly polarizing, separating the population into clearly identified supporters and opponents of the incumbent.

During the campaign leading to the referendum, the "Yes" camp claimed that it was necessary for Morales to remain in office to ensure the continued implementation of the reforms he had been establishing since his arrival in office. Simply put, proponents of the "Yes" option pragmatically argued that Bolivia would benefit from retaining its well-performing president rather than switching to a most likely less competent one (Welp \& Lissidini, 2016). They claimed that it was necessary for Morales to remain in office to further the reform process he launched after his first election, while the opposing side rather accused him of trying to perpetually hold onto power (Alberti, 2016). The "No" camp primed the referendum as a turning point for Bolivian democracy. Morales was accused by the political right of having tilted the electoral playing field in his favour, of being involved in corruption, and to finally seek to overcome the democratic constraints established in the constitution. Some leftist leaders and 
organizations echoed such claims by criticizing him for leaving too little space to other leaders from the Bolivian left.

The referendum was held on February $21^{\text {st }}, 2016$. All registered voters were expected at the polls, voting being mandatory in Bolivia. ${ }^{1}$ To the great surprise of most commentators and observers of Bolivian politics, Morales failed, as 51.3 percent of voters expressed their refusal of the proposed constitutional reform. This unexpected result has been presented as another blow for Latin America's left, especially considering how well supported Morales' government appeared to be. ${ }^{2}$

The Bolivian referendum has the advantage of allowing us to assess the relative explanatory power of both positional and retrospective voting interpretations of the rise and fall of Latin American leftist presidents. Although the referendum referred to a specific issue and not a choice of president as in a regular election, the Bolivian referendum can be expected to have closely approximated a presidential election. Leduc (2002) creates a typology of long- and short-term factors influencing referendum vote choice which supports such expectation. Long-term factors relate to the same set of factors which usually condition electoral behavior - e.g. political parties, social cleavages, and core beliefs - while short-term factors tend to be more closely related to the referendum issue and the campaign - e.g. campaign events and media framing of the issue.

As citizens are unlikely to be willing to spend a considerable amount of time and resources to inform themselves on the issue at hand, they look for cues to help them simplify their decision-making process (Lupia, 1992; 1994). Longterm factors provide simple and readily available cues which operate similarly in elections and referendums, and therefore lead to high levels of consistency between electoral and referendum vote choices. The clearer the divide between the parties on the issue, the more efficiently partisan attitudes can serve as cue-providing mechanisms, leading the referendum outcome to align with such attitudes. Parties therefore serve as trusted groups on which voters rely to act as heuristic devices to guide them in their decision-making process (Clarke, Kornberg \& Stewart, 2004).

In contrast, short-term factors can come into play when voters are presented with conflicting cues from long-term factors, i.e. when parties are internally divided on the issue or social cleavages do not align with issue preferences. The inconsistency of cues gained from long-term factors allow voters' predispositions to be replaced by campaign-specific information as the primary cue-taking source (Zaller, 1992). These referendums are claimed to be most volatile, with

As in most cases of mandatory voting, there was nevertheless some abstention. $84.5 \%$ of registered voters turned out.

2 The Constitutional court eventually allowed Evo Morales to run again by removing the ban on consecutive presidential re-elections. 
voters being more likely to draw on campaign events to engage in a longer learning process to determine their vote choice (Leduc, 2002).

Voting behaviour during the 2016 Bolivian referendum appears most likely to have been influenced by long-term factors, making it resemble the decision-making process which prevails in elections. The Movimiento al Socialismo (MAS) and its allies were strongly supportive of the constitutional referendum, while the opposition virtually rallied around their refusal of it. Moreover, the issue was extremely salient, having been the main topic of discussion in Bolivian politics for multiple weeks. Incidentally, voters could readily rely on their support for the incumbent or the opposition to inform their vote choice, as the issue preference of each group was made extremely clear. We therefore expect voters to have behaved in a way which approximates electoral voting, that is sorting themselves on the referendum issue according to their desire to support or oppose Morales seeking to be re-elected. The aforementioned considerations lead us to focus on the determinants of voters' support for the incumbent or the opposition, expecting that such support drove their referendum vote choice.

The Bolivian context around the time of the referendum make plausible both interpretations of the Latin American left's demise. Indeed, the Bolivian electorate imposing yet another defeat to the Latin American left could quickly be understood as Bolivian voters simply taking part in the regional trend of waning support for leftist policies. Many have offered such interpretation, but others have challenged the positional voting claim, instead pointing toward popular dissatisfaction with the performance of the government on a variety of issues as possible factors explaining the result of the referendum. The purported popular dissatisfaction thus covers a few more issues than the traditional economic one, allowing us to test the retrospective voting interpretation in a variety of ways.

\section{HYPOTHESES}

\section{Retrospective voting}

A standard account of the reasons underlying Bolivia's "No" to Evo Morales would be that citizens were simply unsatisfied with his performance as president and thus took advantage of their opportunity to force him out of office. Valence issue voting has long been demonstrated to be a significant determinant of electoral behaviour in established democracies, with economic performances consistently appearing to be among the most important issues (Campbell et al., 1960; Powell Jr \& Whitten, 1993; Anderson, 2000; Nadeau \& Lewis-Beck, 2001). Recent investigations have found such results to hold in emerging democracies (Gélineau, 2007, 2013; Lewis-Beck \& Stegmaier, 2008; Murillo \& Visconti, 2017). A region-wide comparative study of electoral behaviour in Latin America also 
finds economic perceptions to consistently and significantly outweigh other valence issues (Nadeau et al., 2017). A broad empirical literature thus shows the economy to be at the core of voting behaviour in emerging democracies.

Such interpretation is consistent with findings which point toward negative retrospective evaluations of economic conditions, rather than a shift in voters' policy preferences, as the principal cause of the Latin American left's electoral success in the early 2000s (Murillo et al., 2010). Furthermore, it is also consistent with the economic trajectory of Bolivia since the turn of the $21^{\text {st }}$ century. The generous social policies put in place by Evo Morales were to a large extent financed by the international boom of commodity prices, as the surge in export revenues enabled the president to implement a large number of social programs. Yet, those revenues have dropped during the years leading to the referendum, forcing the government to become more restrictive in its response to the demands of social organizations. Around the time of the referendum, and for the first time since Morales became president, the Bolivian economy faced considerable difficulties which put in jeopardy the livelihood of a substantial proportion of the electorate (Driscoll, 2017). As a result, social conflicts arose in regions of the country whose economy relied most heavily on hydrocarbon extraction (Alberti, 2016). Considering the prevalence of low-income workers among the electoral base of the MAS, this new economic conjuncture could possibly have seriously hindered the fate of Morales' proposed constitutional amendment. Indeed, many social organizations usually sympathetic to his project, notably the labor movements and mining cooperatives, had been facing difficulties due to the drop in the value of commodity prices and started mobilizing more regularly against the Morales administration. In light of their progressive detachment from Morales' project, it appears likely that substantial parts of such groups voted against his constitutional amendment.

The possibility that the MAS' electoral base decided to sanction Evo Morales for worsening economic conditions would echo the results of previous studies that have identified the incapacity of pre-left wave governments to fulfill their voters' socioeconomic demands to be a key issue to account for their declining support (Murillo et al., 2011). One can arguably believe that, as Evo Morales faced increasing economic constraints which limited his capacity to positively respond to the demands of his electoral base, his support dropped consequently. It is thus expected that voters who were facing financial hardships were more likely to hold Morales accountable for their country's economic difficulties. ${ }^{3}$

\footnotetext{
We have opted to rely on personal financial hardships rather than the more standard retrospective economic perceptions for a very practical reason. The Bolivian wave of the 2016/17 LAPOP survey was conducted 13 to 15 months after the referendum. Incidentally, we could not rely on economic perceptions as they measure the evolution of the national economy in the last 12 months before respondents were interviewed, i.e. during the year after the referendum in this case. In contrast, the question on respondents' family income relates to its evolution in the last two years, hence starting during the pre-referendum period. Moreover, this question has the advantage of being more closely related to the Bolivian context, in which the health of the national economy strongly conditioned the capacity of the Morales administration to implement social programs and improve the material conditions of the poorer stratums of the population.
} 
H1a: Voters who faced financial hardships are more likely to have voted "No."

Although economic perceptions have long been shown to dominate valence issues, other ones can also factor in to varying degrees in different contexts. During the weeks leading up to the referendum, a lot of media attention was given to corruption scandals involving the MAS, the president's entourage, and the president himself. The broad coverage of such corruption allegations made the information easily accessible, hence possibly weighing in the decision-making process of a large amount of voters (Downs, 1957; Fiorina, 1981).

Yet, the relationship between corruption and retrospective voting is not a clearcut one. In fact, the empirical literature offers mixed results regarding the impact of corruption information on incumbent vote share. Most scholarly work on the topic has found individual perceptions of corruption to decrease the overall turnout, but some authors argue that such decrease favors the opposition (Peters \& Welch, 1980; Ferraz \& Finan, 2008; Winters \& Weitz-Shapiro, 2013), whereas others claim that it favors the incumbent (McCann \& Dominguez, 1998; Davis et al., 2004). Chong et al. (2014) hint at a possible explanation for this uneven impact of corruption on incumbent success, stating that voters already suspect corruption to be present and therefore only punish the incumbent if such practice appears to be more widespread than they expected. Moreover, they posit that for the electorate to punish the incumbent, voters need to perceive the opposition as being intrinsically "cleaner", rather than view corruption as an equilibrium in which all elected officials would engage.

Considering Bolivia's long history of political corruption, it is unclear whether voters might have believed that opposition parties would make a more ethical use of public resources. Yet, one could certainly argue that corruption appeared so rampant at the time of the referendum that voters could at least think of opposition parties as lesser evils regarding their potential use of public funds. Furthermore, the corruption scandals specifically targeted the MAS rather than the political system as a whole. The clarity of responsibility regarding which parties are involved in corruption has been claimed to be an important condition facilitating electoral punishment of the incumbent (Gingerich, 2009), and this condition was definitely fulfilled at the time of the referendum. Moreover, wide media coverage of corruption scandals has also been demonstrated to facilitate electoral sanctioning of the incumbent (Chang, Golden, \& Hill, 2010). Considering the amount of media attention that corruption scandals gathered at the time, it appears possible that Bolivian voters decided to punish Evo Morales for his incapacity to control corruption by voting against his proposed constitutional reform to force him out of office.

H1b: Voters who perceive political corruption to be rampant are more likely to have voted "No."

The third type of dissatisfaction which appears to have possibly played a role in the referendum result is democratic dissatisfaction. Such interpretation has not 
been put forward as much as the previous ones to account for the referendum result, but it is nevertheless consistent with the evolution of Bolivian democracy under the presidency of Evo Morales. Harassment, violence, and abuse of state resources to intimidate the opposition have all characterized Bolivian politics since Morales came to power (Madrid, 2011; Levitsky \& Loxton, 2013). Although free and fair elections have not been challenged, and have in fact been used to legitimate the regime, the Morales administration has severely undermined the opposition's capacity to mount a fair challenge to the incumbent. Various international organizations have also criticized the Bolivian government for hampering civil rights during the years leading to the referendum (Freedom House, 2015; Human Rights Watch, 2015). The main criticisms have focused on the reduction of judicial independence, the impunity of perpetrators of human rights abuses, and numerous limitations of political contestation rights.

It thus appears possible that Bolivian voters decided to stop Evo Morales from further eroding the quality of their country's democracy, as Evo Morales had previously concentrated political powers into his hands, tilted the playing field in his favor, and was now seeking to overcome the presidential term limit once more. ${ }^{4}$ Moreover, the emphasis by the "No" camp on the issue of democratic erosion under Morales is likely to have made it particularly salient, especially considering the absence of a specific policy choice at play during the referendum. It is therefore expected that voters having refused the proposed constitutional amendment will display higher levels of dissatisfaction with the state of civil rights in their country.

H1c: Voters who are unsatisfied with the state of civil rights in their country will be more likely to have voted "No."

\section{Positional voting}

Most scholarly work on electoral behaviour in emerging democracies presents positional voting as an unlikely scenario. The volatility of party systems (Scully, 1995), their inchoate nature (Kitschelt et al., 2010), frequent bait-and-switch tactics (Stokes, 2001), and low levels of sophistication among the electorates (Grönlund \& Milner, 2006) are all factors which are identified as making the expression of policy preferences through the vote an unlikely behaviour. Yet, in a recent investigation, Baker \& Greene (2015) find compelling evidence of positional voting across the Latin American region, and assert that positional voting has simply been inappropriately tested in previous studies.

The findings of Baker and Greene (2015) lend credibility to a frequent claim suggesting that Latin America is currently witnessing a desire among its citi-

Morales had already been re-elected twice, although the Bolivian constitution permitted only one re-election to its president. He was allowed to do so because the new constitution had been adopted in 2009, and his first election came under the previous constitution. The 2009 election was thus counted as his first election under the current constitution, and the 2014 election then counted as his only attempt at re-election. 
zens to break away from the leftist policies adopted during the first decade of the $21^{\text {st }}$ century. More specifically, such interpretation implies that the political swing toward the election of rightist presidents the region is experiencing would be the expression of a desire among its voters to elect governments favoring economic growth through more liberal policies.

Once again, the economy would be a key issue in understanding such desire to favour the implementation of rightist policies. Looking at the initial left turn, many scholars have presented it as the result of voters rejecting neoliberal policies and choosing to support candidates promoting redistribution policies (Hershberg \& Rosen, 2006; Baker \& Greene, 2011; Grugel \& Riggirozzi, 2012). Voters would thus have shifted their support toward statist economic programs and voted for the candidates who proposed to implement the changes they desired. Turning to the more recent downfall of the Latin American left, the mere extension of that argument would be that voters have shifted their support toward liberal economic policies and thus quit supporting leftist candidates.

Consequently, for the result of the Bolivian referendum to be the result of voters' positional issue preferences, we should observe among those who voted "No" a systematic trend toward a more market-oriented attitude regarding economic policies, as opposed to an interventionist stance. Two economic issues have been particularly salient under the Morales administration: state ownership of enterprises and wealth redistribution. Those two issues were, in fact, highly interconnected as the various social policies that were implemented to alleviate poverty were to a large extent financed by the partial nationalization of many private enterprises (Molina, 2010). If the result of the referendum expressed a desire among voters to break away from the reforms implemented under the Morales administration, we expect voters' preferences regarding wealth redistribution and nationalizations of enterprises to be significant predictors of their vote. "No" voters should therefore display more rightist stances regarding state ownership of enterprises and wealth redistribution.

H2a: Voters who disapprove state ownership of enterprises are more likely to have voted "No."

H2b: Voters who disapprove statist policies to reduce economic inequalities are more likely to have voted "No."

\section{DATA ANALYSIS}

The analysis presented in this paper relies on public opinion data taken from the 2016-2017 LAPOP survey conducted in Bolivia. ${ }^{5}$ Between March and May 2017, 1,691 Bolivian citizens were questioned about various political issues. 
The sample was probabilistic and designed to be representative of the national population, with interviews conducted face-to-face in Spanish. These data constitute the only large-scale public opinion survey asking Bolivian citizens about their vote choice during the referendum. The use of such data therefore allows this article to complement other studies that have investigated the referendum from an aggregated perspective (Driscoll, 2017).

Our outcome variable is respondents' vote choice during the referendum. The question asked respondents "¿Cómo votó usted en el Referéndum de febrero de 2016?" They could answer that they either voted "Yes", voted "No", did not vote, or cancelled their vote. Such vote recall questions have long been known to be affected by some measurement error (Weir, 1975). Looking at the distribution of our outcome, measurement error seems to be revealed in that a slightly greater proportion of survey respondents mentioned they voted in favour of the constitutional amendment than the actual proportion during the referendum. In our sample distribution, $54.2 \%$ of respondents answered that they had voted in favour of the amendment, while the population proportion stands at $48.7 \%$, a 5.5 percentage points difference. Incidentally, while there is some bandwagonning occurring, its magnitude remains fairly limited. Furthermore, the recent literature on vote recall questions warrants their usefulness, suggesting that inferences drawn from models using such questions barely differ from those of models relying on more proximate measures of vote choice (Dassonneville \& Hooghe, 2017). Accordingly, our use of a recall vote question should allow us to reach sound conclusions about the determinants of voting behavior during the referendum.

Figure 1 presents the distribution of vote choice during the referendum across three key variables. The left panel shows that vote choice in the 2014 presidential election is highly correlated with vote choice during the referendum, although a non-negligible portion of voters, especially among those who supported Morales in 2014, have changed their vote. More than one out of five respondents in our sample who declared having voted for Morales in 2014 have opposed his constitutional amendment in the referendum, a significant rate of defection. The proportion of respondents who took the opposite route - i.e. voted "Yes" after having voted for the opposition in 2014 - is much more modest. ${ }^{6}$

It should be noted that the 2014 presidential election vote choice variable, much more so than the referendum vote choice variable, is affected by the bandwagonning effect discussed previously. Accordingly, as a robustness check, an alternative model presented in the Appendix is estimated without the presidential vote choice variable. The substantive interpretation of the results remains similar, with the estimates of the predictors tending to be higher. 
Figure 1. Distribution of vote choice in the referendum across key variables. Note: Percentage in each bar represents the proportion of respondents in each answer category that voted No.

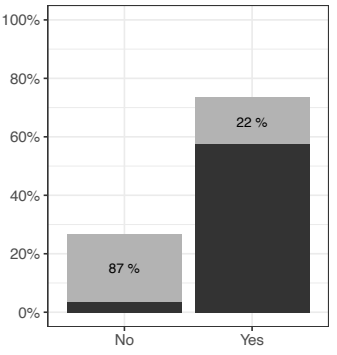

Vote for Evo Morales in 2014 Presidential Election

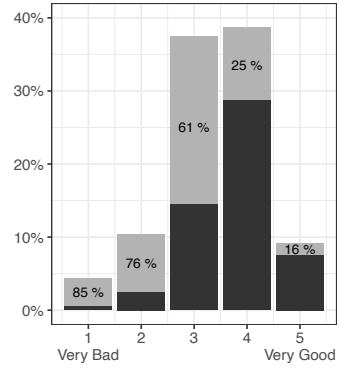
Evaluation of Presidential
Performance

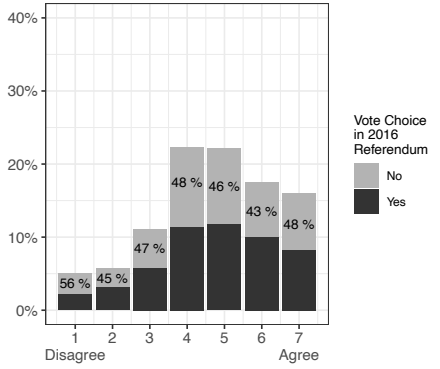

Democracy Best Form

The center panel shows the distribution of referendum votes stratified by respondents' evaluation of the presidents' work in office, with higher values indicating greater approval. The plot shows a very strong correlation between the two variables, as those who are satisfied with the president's work are much more likely to have voted "Yes" than their unsatisfied counterparts. Finally, the right panel uses the same strategy, this time conditioning on respondents' attitude toward democracy, with higher values representing greater support for democracy as a form of government. The story that emerges out of that third plot is significantly different, as there is no indication of a correlation between attitudes toward democracy and vote choice during the referendum, as the proportion of "Yes" votes during the referendum is close to $50 \%$ across all seven answer categories.

The evidence presented in Figure 1 supports our theoretical expectation that voting behaviour during the referendum was similar to voting behaviour during elections. Indeed, voters' attitude toward the president appears to have constituted the primary cue-taking source to inform their referendum vote choice. If voters had made a choice based on the constitutional amendment per se, we would expect to see a greater refusal of the amendment among supporters of democracy, as the amendment was intended to remove an institutional constraint on presidential power. Accordingly, we would expect to see a negative correlation between support for democracy and "Yes" votes: the more supportive of democracy a respondent is, the more likely s/he would be expected to have expressed support for institutional constraints on the president through a "No" vote. Yet, this is absolutely not what we observe, as referendum vote choice appears to be unrelated to democratic attitudes. It is rather strongly correlated with presidential approval, which suggests that what drove vote choice during the referendum was not short-term factors related to the referendum issue, but rather long-term factors such as partisan attitudes which similarly influence electoral voting decisions.

To understand the dynamics of voting behaviour during the referendum, we focus on the attitudinal determinants of the vote. Our hypotheses are tested by 
the inclusion in our logistic regression model of variables measuring the attitudes we expect to have possibly played a role on citizens' vote choice. ${ }^{7}$ For the valence issues, these are the evaluations of one's household financial situation, the perception of high political corruption, and dissatisfaction with the state of civil rights. Turning to the positional issues, we include a variable measuring respondents' level of agreement with the statement that the state should not own companies, and with another one positing that the state should not establish policies to redistribute wealth. Those variables capture the main attitudes that are expected to have played a role in Bolivian voters' refusal of the constitutional amendment. While the data has been collected some time after the referendum, for most issues there are no obvious reasons to expect that attitudes have systematically shifted in the months that followed the referendum. The main issue concerns the corruption variable, as some of the major allegations of corruption that were made during the referendum campaign have later been proved to be unsupported. A significant amount of media attention during the campaign focused on claims made by the opposition that the president had engaged in influence-trafficking in trying to secure government contracts for a firm employing his former partner Gabriela Zapata. ${ }^{8}$ Accordingly, with those allegations being found to be unsupported after the referendum, perceptions of corruption were possibly lower during the fielding of the survey, which would bias our estimate downward for this specific variable. Our results therefore need to be understood as providing a lower-bound on the association between perceptions of corruption and vote choice during the referendum.

To allow for the possibility that some voters' preference on the particular constitutional amendment - irrespective of their attitude toward the president - might have determined their vote choice, we include a variable capturing voters' level of approval with the statement that democracy is the best form of government. We expect support for democracy to be correlated with "No" votes, since voters were asked during the referendum to allow the removal of a constraint on presidential power. The model also includes a control variable for vote choice in the 2014 presidential election as we expect that supporting (or not) the president will be correlated with both retrospective evaluations and referendum vote choice. Finally, controls are also added for standard sociodemographic indicators, geographical indicators, and reception of a form of conditional cash transfer (CCT).

The regression results are presented in Figure 2. The predictors have all been standardized by subtracting to each observation the mean value of the variable and dividing them by the standard deviation of the variable. The magnitude of the coefficients can therefore be directly compared. It should be noted that the inclusion of a control for respondents' vote in the previous presidential election

Detailed description of the construction and coding of all variables included in the regression models can be found in the Appendix.

The author would like to thank the journal editor for raising this issue. 
imposes a significant burden to our hypotheses tests. The results present the association between our predictors and referendum vote choice once the very strong association between vote choice during the 2014 presidential election and the 2016 referendum has been taken into account. The results therefore provide very conservative coefficient estimates, a modeling strategy which is appropriate considering the time lapse between the referendum and the survey. Therefore, while the survey would ideally have been conducted closer to the referendum, the conservative approach used in the specification of the model decreases our vulnerability to falsely rejecting the null hypothesis of no relationship between the key predictors and the outcome. ${ }^{9}$

Figure 2. Results of logistic regression. Note: Points represent standardized coefficient estimates, grey bars represent $95 \%$ confidence intervals, black bars represent $90 \%$ confidence intervals. Constant included but not shown. Reference category for the regional dummies is the Media Luna. $n=688$. AIC $=673.724$.

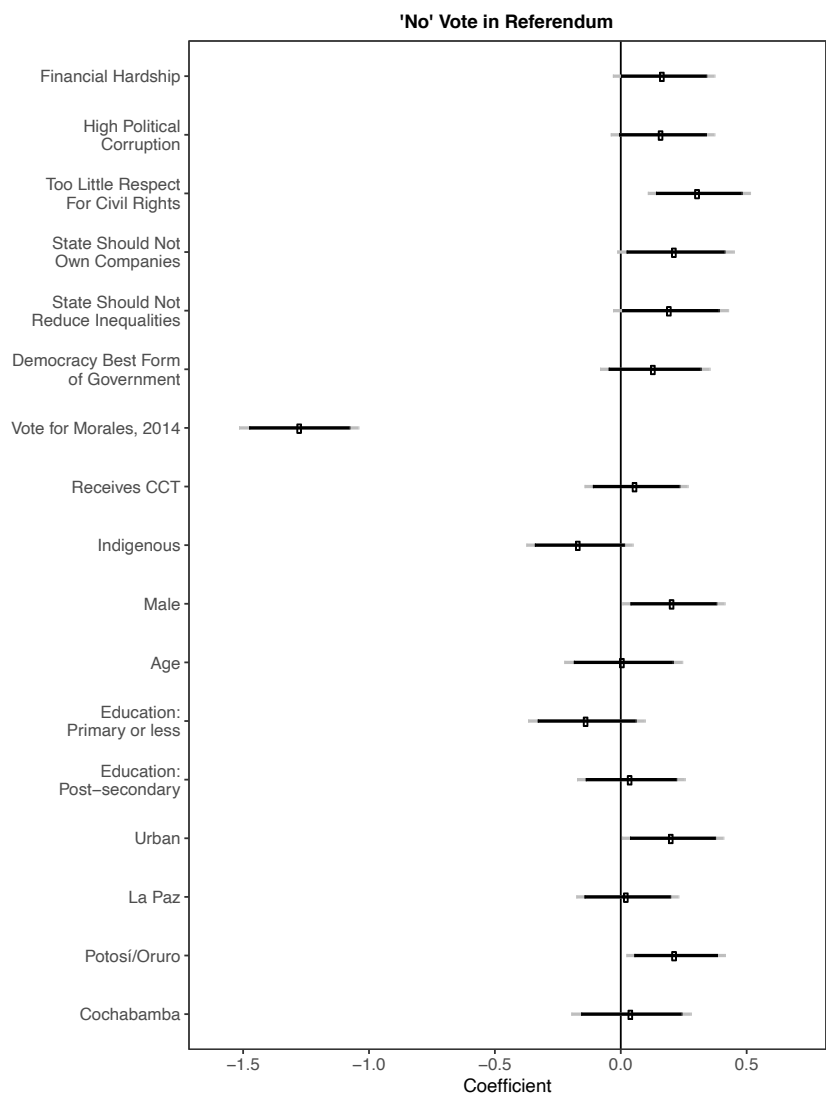

9 An alternative modeling strategy, without the control for presidential vote choice, is presented in the Appendix. As expected, the coefficient estimates for our key predictors tend to be higher in such alternative modeling strategy, but their size relative to one another remains similar. 
The three predictors testing the retrospective voting interpretation (Financial hardship, High political corruption, and Too little respect for civil rights) find unequal support. There is a significant amount of empirical support for the democratic dissatisfaction hypothesis, as people who believe there is too little respect for civil rights are significantly more likely to have voted "No" than their more satisfied counterparts. The point estimate is significantly different from zero, which allows us to be confident that there exists a relationship between vote choice in the referendum and dissatisfaction with the state of civil rights in Bolivia. Among the predictors testing the two theories in which we are interested, democratic dissatisfaction is the only one to receive unqualified empirical support.

The coefficient estimate for perceptions of political corruption provides an ambiguous case. While it falls in the expected direction, it fails to reach conventional levels of statistical significance. Yet, we should reiterate that this estimate provides a lower bound of its impact on vote choice. Indeed, as many allegations of corruption have been proven unfounded in the months that followed the referendum, it is likely that respondents' perception of political corruption decreased between the referendum campaign and the fielding of the survey. If such possibility were true, this would mean that perceptions of corruption possibly played a greater role in the referendum than our regression results suggest. Keeping in mind Leduc's theoretical framework on the determinants of vote choice during referendums (Leduc, 2002), it also appears possible that partisan divisions on the referendum issue were so clear that short-term factors such as campaign events had little leverage over voters' decision-making process. Voters having already made up their mind based on their partisan attitudes, it is possible that alleged corruption scandals weighted very little on the referendum outcome. Such discussion remains tentative, as the jury remains out over the impact of corruption scandals on the referendum outcome. Our analysis cannot reject the possibility that perceptions of political corruption did play a role as many observers of Bolivian politics have claimed, although there are also theoretical reasons to expect that such issue had a limited impact.

Regarding our third retrospective evaluation, the model provides qualified support for the hypothesis that economic distress played a role in the referendum outcome. Reaching statistical significance at the fairly permissive $\mathrm{p}<.1$ level, the coefficient on the Financial hardship predictor does suggest that respondents who experienced a challenging financial situation were more likely to have voted against the constitutional amendment.

Some qualified support is also found for the positional voting interpretation. Respondents who believe that the state should not own companies are estimated to be more likely than others to have voted "No", although the coefficient of the predictor only reaches statistical significance at the $p<.1$ level. Our other positional issue, that of wealth redistribution, fails for its part to reach statistical significance, although its point estimate is nearly identical to that of preference toward state ownership of companies. The latter result can possibly be 
explained by the fact that wealth redistribution is a more abstract and arguably more consensual issue, as opposed to state ownership of enterprises which relates more clearly to one's policy preferences. Nevertheless, the results suggest that the leverage of positional issues on voters' choice during the referendum remains more debatable than that of retrospective evaluations.

Consistent with the bivariate analysis presented in Figure 1, our regression results suggest that attitudes toward democracy did not play a key role in citizens' vote choice during the referendum, as the Democracy Best Form of Government predictor fails to reach statistical significance. This finding lends further support to our belief that Bolivian voters behaved as if the referendum had been an election, rather than voting on the basis of their opinion toward the content of the constitutional amendment per se. It is coherent with the framing of the referendum as a plebiscite on Evo Morales and his performance in office by both his opponents and supporters during a heavily personalized campaign.

Finally, it is interesting to note that respondents from the Potosí/Oruro region are found to be significantly more likely to have voted "No" than the respondents from the reference group, i.e. the Media Luna region. This is especially surprising considering that the latter region has usually been considered the most strongly opposed to the Bolivian president, while the Potosí/Oruro region is rather considered to be one of the strongholds of the MAS. It is the sole regional dummy variable whose estimate reaches statistical significance, which suggests that there is something specific to this region that the rest of the model's predictors do not fully capture. A variety of events have occurred during the months leading to the referendum which could possibly explain why voters of this traditional MAS stronghold are likely to have withdrawn their support to the president. Most significantly, the region was highly impacted by the international drop of commodity prices, as its economy relied extensively on the mining industry. Several protests have been held between the 2014 election and the referendum to criticize the Morales administration for its lack of investment in the region as foreign direct investment plummeted from 2014 to 2015 (Alberti, 2016). ${ }^{10}$ In this regard, our results are consistent with those of Driscoll (2017), who found that there had been a significant drop in pro-MAS vote share in mining communities between the 2014 election and the 2016 referendum. This finding thus lends credibility to the possibility that Bolivian voters most deeply impacted by the economic downturn the country was facing decided to sanction Morales by refusing him the possibility to seek re-election.

In sum, the results suggest that two factors most significantly contributed to Evo Morales' referendum defeat: his government failing to fulfill its voters' demands regarding the quality of democracy, and also its incapacity to appease the growing discontent in the Potosí and Oruro departments. Regarding dissatisfaction with the state of civil rights protection, the Bolivian opposition pre- 
senting the referendum as a turning point for the country's democracy might have primed the issue and made it salient to voters, especially considering the fact that there were no policy choices directly at play during the referendum. In this regard, we thus find strong evidence supporting a retrospective voting interpretation.

Turning to the second determinant factor, even after controlling for a variety of attitudinal measures, residing in the Potosí/Oruro region remained a significant predictor of a "No" vote. It thus seems that the confrontations between the MAS and the Potosí/Oruro residents which occurred throughout 2015 left a profound scar which altered their voting behaviour. Neither retrospective evaluations nor positional preferences directly succeed at identifying the reasons underlying the sudden change in the voting pattern of this region of the country which had, until the referendum, been one of the most supportive of the MAS. Yet, the contestation started from dissatisfaction with the economic downturn the region was facing, and was eventually fueled by the perception among residents of the region that the MAS was not addressing their demands. Incidentally, economic hardships might have exerted an indirect impact on Morales' defeat, as it fostered the regional movement of contestation which led the voters of the region to quit supporting him.

\section{CONCLUSION}

Much work has been done to account for the resurgence of the Latin American left during the first decade of the $21^{\text {st }}$ century. Micro-level studies have mostly debated whether the phenomenon is the result of voters issuing a retrospective or a positional vote. This article has argued that the contemporary collapse of most leftist regimes elected during the left turn provides a new opportunity to contribute to the debate on the determinants of Latin America's swings in presidential ideological orientation.

Investigating the case of the 2016 Bolivian referendum, this article has assessed the explanatory power of two distinct interpretations of voting behaviour to account for the choice of Bolivian voters. The first interpretation relies on the retrospective voting theory and posits that ideological swings in Latin America are the result of mere dissatisfaction with the performance of governments in office. The second interpretation presents such swings as the result of voters wittingly supporting parties and candidates holding different policy preferences than their incumbent governments.

To test both interpretations, we relied on survey data collected among Bolivian voters which we analyzed through regression analysis. The results indicate that dissatisfaction with the way the Morales administration handled the issue of civil rights protection, and having experienced regional movements of contestation are the strongest predictors of interest to account for a "No" vote. While not entirely discarding the relevance of positional issues to account for 
Bolivian voters' behaviour, the results are nevertheless most consistent with a retrospective interpretation of Morales' defeat. The gap between the demands of Bolivian voters regarding the protection of civil rights and the way the Morales administration handled the issue appears to have led voters to sanction their president in his attempt to modify the constitution. Moreover, while retrospective assessments do not directly account for the behaviour of voters from the Potosí and Oruro departments, the region's economic downturn appears to have weakened the support of its voters for the MAS, which led them to turn their back on Morales during the referendum.

This article incidentally joins a large body of scholarly work which found the vote choice of Latin American citizens to be most significantly determined by the capacity of their governments to fulfill their demands (Stokes, 2001; Murillo et al., 2010; Remmer, 2012; Nadeau et al., 2017). It extends on those contributions by showing that retrospective evaluations can also account for referendum voting. Yet, even if supporting the old claim that valence issues dominate voting behaviour in emerging democracies, the results also suggest that voters have the capacity to look further than economic conditions when making their vote choice. Hence, citizens in new democracies might possibly be mainly looking for well-performing governments, but they appear to have the capacity to assess such performance on more than a single front. This finding is reassuring since it leads us to believe that underperforming incumbents might not be able to avoid electoral accountability merely because of favorable economic conditions. Governmental accountability in emerging democracies most likely revolve around valence issues more than anything else, but the Bolivian case suggests that voters might have the capacity to assess a wider set of such issues than what is usually thought, and might not be constraining their expression of such dissatisfaction to electoral settings.

\section{REFERENCES}

Achen, Christopher H. (1975). Mass Political Attitudes and the Survey Response. American Political Science Review, 69(4), 1218-1231.

Alberti, Carla (2016). Bolivia: La Democracia a Una Década Del Gobierno Del MAS. Revista de Ciencia Política, 36(1), 27-49.

Altman, David (2010). Plebiscitos, Referendos E Iniciativas Populares en América Latina : ¿Mecanismos de Control Político O Políticamente Controlados? Perfiles latinoamericanos, 18(35), 9-34.

Altman, David (2011). Direct Democracy Worldwide. New York: Cambridge University Press.

Anderson, Christopher J. (2000). Economic Voting and Political Context: A Comparative Perspective. Electoral Studies, 19(2), 151-170.

Ansolabehere, Stephen, Jonathan Rodden, and James M. Snyder (2008). The Strength of Issues: Using Multiple Measures to Gauge Preference Stability, Ideological Constraint, and Issue Voting. American Political Science Review, 102(2), 215-232.

Arnold, Jason Ross and David J. Samuels (2011). Evidence From Public Opinion. In The Resurgence of the Latin American Left, edited by Steven Levitsky \& Kenneth M. Roberts. Baltimore: The Johns Hopkins University Press, 31-51. 
Baker, Andy and Kenneth F. Greene (2011). The Latin American Left's Mandate: Free-market Policies and Issue Voting in New Democracies. World Politics, 63(1), 43-77.

Baker, Andy and Kenneth F. Greene (2015). Positional Issue Voting in Latin America. In The Latin American Voter: Pursuing Representation and Accountability in Challenging Contexts, edited by Ryan E. Carlin, Matthew M. Singer, \& Elizabeth J. Zechmeister . Ann Arbor: University of Michigan Press, 173-195.

Brinks, Daniel M. (2007). The Judicial Response to Police Killings in Latin America: Inequality and the Rule of Law. New York: Cambridge University Press.

Campbell, Angus, Philip E. Converse, Warren E. Miller and Donald E. Stokes (1960). The American Voter. Chicago: University of Chicago Press.

Chang, Eric C., Miriam A. Golden and Seth J. Hill (2010). Legislative Malfeasance and Political Accountability. World Politics, 62(2), 177-220.

Chong, Alberto, Ana L. De La O, Dean Karlan and Leonard Wantchekon (2014). Does Corruption Information Inspire the Fight or Quash the Hope? A Field Experiment in Mexico on Voter Turnout, Choice, and Party Identification. The Journal of Politics, 77(1), 55-71.

Clarke, Harold D., Allan Kornberg and Marianne C. Stewart (2004). Referendum Voting as Political Choice: The Case of Quebec. British Journal of Political Science, 34, 345-355.

Dassonneville, Ruth and Marc Hooghe (2017). The Noise of the Vote Recall Question: The Validity of the Vote Recall Question in Panel Studies in Belgium, Germany, and the Netherlands. International Journal of Public Opinion Research, 29(2), 316-338.

Davis, Charles L., Roderic Ai Camp and Kenneth M. Coleman (2004). The Influence of Party Systems on Citizens' Perceptions of Corruption and Electoral Response in Latin America. Comparative Political Studies, 37(6), 677-703.

Downs, Anthony (1957). An Economic Theory of Democracy. New York: Harper \& Row.

Driscoll, Amanda (2017). Bolivia's “Democracy in Transition": More Questions Than Answers in 2016. Revista de Ciencia Política, 37(2), 255-279.

Ferraz, Claudio and Frederico Finan (2008). Exposing Corrupt Politicians: The Effects of Brazil's Publicly Released Audits on Electoral Outcomes. The Quarterly Journal of Economics, 123(2), 703-745.

Fiorina, Morris P. (1981). Retrospective Voting in American National Elections. New Haven: Yale University Press.

Freedom House. (2015). Freedom in the world. Retrieved from: https:/ freedomhouse.org/ sites/default/files/01152015_FIW_2015_final.pdf

Gélineau, François (2007). Presidents, Political Context, and Economic Accountability: Evidence From Latin America. Political Research Quarterly, 60(3), 415-428.

Gélineau, François (2013). Electoral Accountability in the Developing World. Electoral Studies, 32(3), 418-424.

Gingerich, Daniel W. (2009). Corruption and Political Decay: Evidence From Bolivia. Quarterly Journal of Political Science, 4(1), 1-34.

Grönlund, Kimmo and Henry Milner (2006). The Determinants of Political Knowledge in Comparative Perspective. Scandinavian Political Studies, 29(4), 386-406.

Grugel, Jean and Pía Riggirozzi (2012). Post-Neoliberalism in Latin America: Rebuilding and Reclaiming the State After Crisis. Development and Change, 43(1), 1-21.

Hershberg, Eric and Fred Rosen (2006). Turning the Tide? In Latin America After Neoliberalism: Turning the Tide in the 21st Century, edited by Eric Hershberg and Fred Rosen. New York: The New Press, 1-25.

Human Rights Watch. (2015). World Report 2015. Retrieved from: https://www.hrw.org/ world-report/2015/country-chapters/bolivia

Kitschelt, Herbert, Kirk A. Hawkins, Juan Pablo Luna, Guillermo Rosas and Elizabeth J. Zechmeister (2010). Latin American Party Systems. New York: Cambridge University Press.

Kouba, Karel (2016). Party Institutionalization and the Removal of Presidential Term Limits in Latin America. Revista de Ciencia Política, 36(2), 433-457.

Leduc, Lawrence (2002). Opinion Change and Voting Behavior in Referendums. European Journal of Political Research, 41, 711-732. 
Levitsky, Steven and James Loxton (2013). Populism and Competitive Authoritarianism in the Andes. Democratization, 20(1), 107-136.

Levitsky, Steven and Kenneth M. Roberts (2011). Latin America's Left Turn. In The Resurgence of the Latin American Left, edited by Steven Levitsky \& Kenneth M. Roberts. Baltimore: The John Hopkins University Press, 1-28.

Lewis-Beck, Michael S. and Mary Stegmaier (2008). The Economic Vote in Transitional Democracies. Journal of Elections, Public Opinion and Parties, 18(3), 303-323.

Lupia, Arthur (1992). Busy Voters, Agenda Control, and the Power of Information. American Political Science Review, 86(2), 390-403.

Lupia, Arthur (1994). Shortcuts Versus Encyclopedias: Information and Voting Behavior in California Insurance Reform Elections, American Political Science Review, 88(1), 63-76.

Madrid, Raúl (2011). Bolivia: Origins and Policies of the Movimiento al Socialismo. In The Resurgence of the Latin American Left, edited by Steven Levitsky \& Kenneth M. Roberts. Baltimore: The John Hopkins University Press, 239-259.

McCann, James A. and Jorge I. Domínguez (1998). Mexicans React to Electoral Fraud and Political Corruption: An Assessment of Public Opinion and Voting Behavior. Electoral Studies, 17(4), 483-503.

McCann, James A. and Chappell Lawson (2003). An Electorate Adrift? Public Opinion and the Quality of Democracy in Mexico. Latin American Research Review, 60-81.

Molina, George Gray (2010). The Challenge of Progressive Change Under Evo Morales. In Leftist Governments in Latin America: Successes and Shortcomings, edited by Kurt Weyland, Raúl Madrid and Wendy Hunter. New York: Cambridge University Press, 57-76.

Murillo, M. V., Oliveros, V., \& Vaishnav, M. (2010). Electoral Revolution or Democratic Alternation? Latin American Research Review, 45(3), 87-114.

Murillo, María Victoria, Virginia Oliveros and Milan Vaishnav (2011). Economic Constraints and Presidential Agency. In The Resurgence of the Latin American Left, edited by Steven Levitsky \& Kenneth M. Roberts. Baltimore: The John Hopkins University Press, 52-70.

Murillo, María Victoria and Giancarlo Visconti (2017). Economic Performance and Incumbents' Support in Latin America. Electoral Studies, 45, 180-190.

Nadeau, Richard and Michael S. Lewis-Beck (2001). National Economic Voting in US Presidential Elections. Journal of Politics, 63(1), 159-181.

Nadeau, Richard, Michael S. Lewis-Beck, Éric Bélanger, Mathieu Turgeon and François Gélineau (2017). Latin American Elections: Choice and Change. Ann Arbor: University of Michigan Press.

Peters, John G. and Susan Welch (1980). The Effects of Charges of Corruption on Voting Behavior in Congressional Elections. American Political Science Review, 74(3), 697-708.

Powell Jr, G. Bingham and Guy D. Whitten (1993). A Cross-National Analysis of Economic Voting: Taking Account of the Political Context. American Journal of Political Science, 37(2), 391-414.

Remmer, Karen L. (2012). The Rise of Leftist-Populist Governance in Latin America: The Roots of Electoral Change. Comparative Political Studies, 45(8), 947-972.

Scully, Timothy R. (1995). Building Democratic Institutions: Party Systems in Latin America. Stanford: Stanford University Press.

Stokes, Susan C. (2001). Mandates and Democracy: Neoliberalism by Surprise in Latin America. New York: Cambridge University Press.

Weir, Blair T. (1975). The Distortion of Voter Recall. American Journal of Political Science, 19, 53-62.

Welp, Yanina and Alicia Lissidini (2016). Democracia Directa, Poder y Contrapoder: Análisis del Referendo del 21 de Febrero de 2016 en Bolivia. Bolivian Studies Journal/Revista de Estudios Bolivianos, 22, 162-190.

Weyland, Kurt (2011). The Left: Destroyer or Savior of the Market Model? In The Resurgence of the Latin American Left, edited by Steven Levitsky \& Kenneth M. Roberts. Baltimore: The John Hopkins University Press, 71-92. 
Winters, Matthew S. and Rebecca Weitz-Shapiro (2013). Lacking Information or Condoning Corruption: When Do Voters Support Corrupt Politicians? Comparative Politics, 45(4), 418-436.

Zaller, John R. (1992). The Nature and Origins of Mass Opinion. New York: Cambridge University Press.

Received: 29 April, 2019

Accepted: 23 September, 2020

Maxime Blanchard is a PhD student in political science at McGill University, in Montréal, Canada. His research investigates the determinants of electoral behaviour, with a specific focus on the development and evolution of political attitudes. He specializes in the use of innovative techniques to overcome the limitations of public opinion surveys. E-mail: maxime.blanchard@mail.mcgill.ca 


\section{APPENDIX}

\section{Factorial analysis}

Figure A. Factorial analysis of perceptions of civil rights measurement scale.

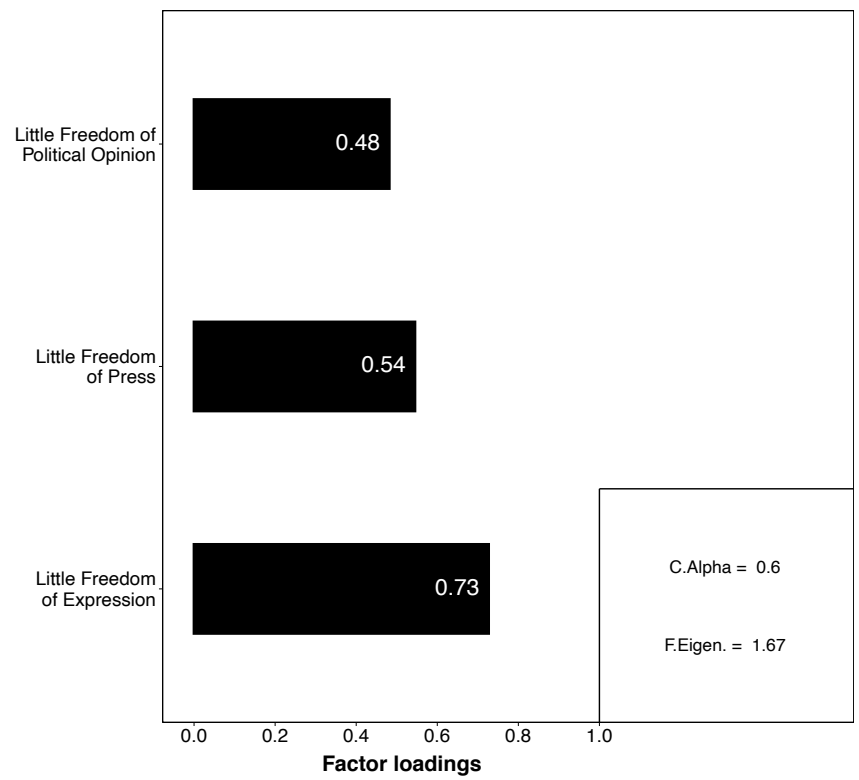




\section{Alternative model specifications}

Figure B. Results of logistic regression, alternative specification not controlling for vote choice in the 2014 presidential election. Note: Points represent standardized coefficient estimates, grey bars represent $95 \%$ confidence intervals, black bars represent $90 \%$ confidence intervals. Constant included but not shown. Reference category for the regional dummies is the Media Luna. $n=921$. AIC $=1,117.885$.

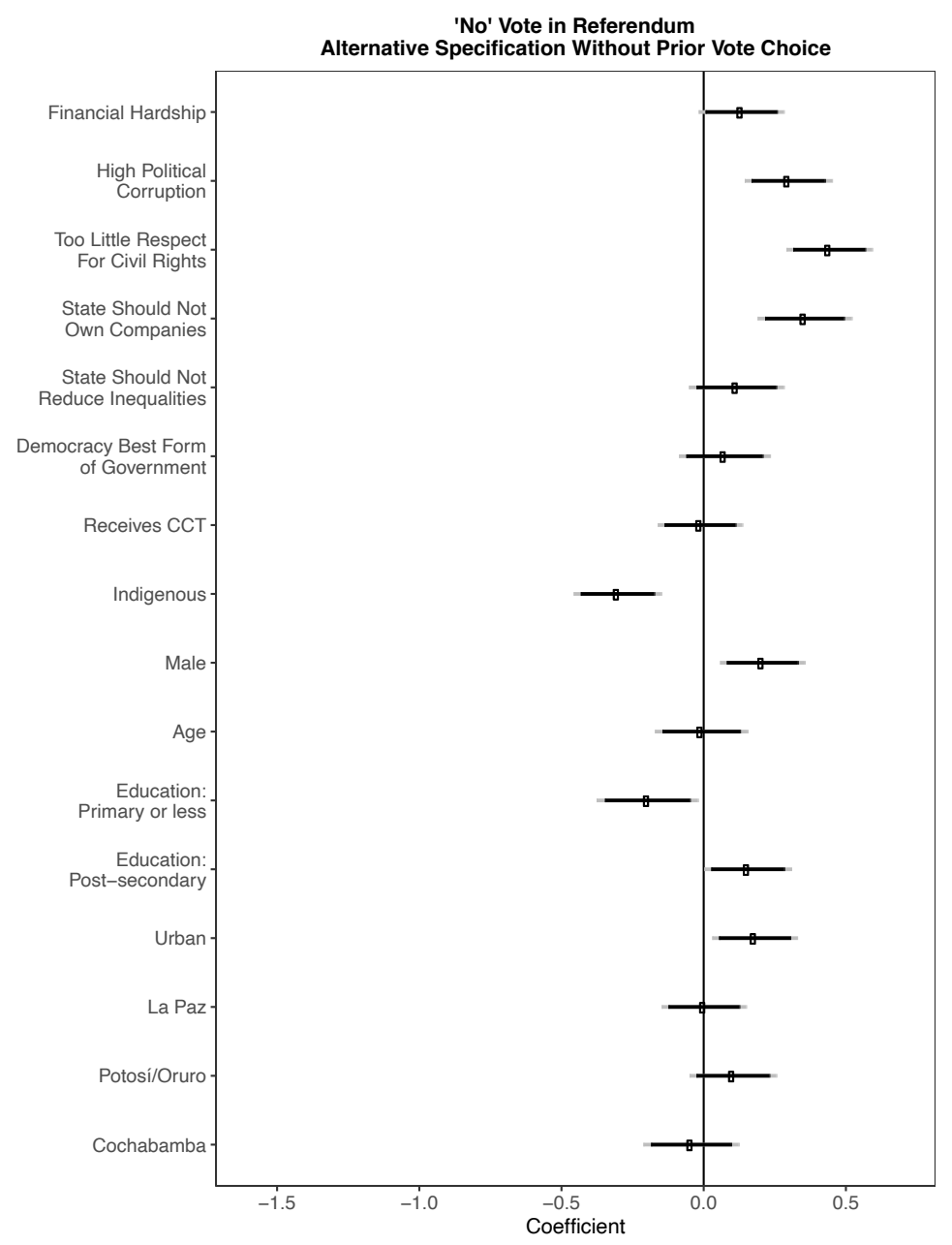


Figure C. Results of logistic regression, alternative specification controlling for ideological self-placement. Note: Points represent standardized coefficient estimates, grey bars represent $95 \%$ confidence intervals, black bars represent $90 \%$ confidence intervals. Constant included but not shown. Reference category for the regional dummies is the Media Luna. $n=643$. AIC $=614.096$.

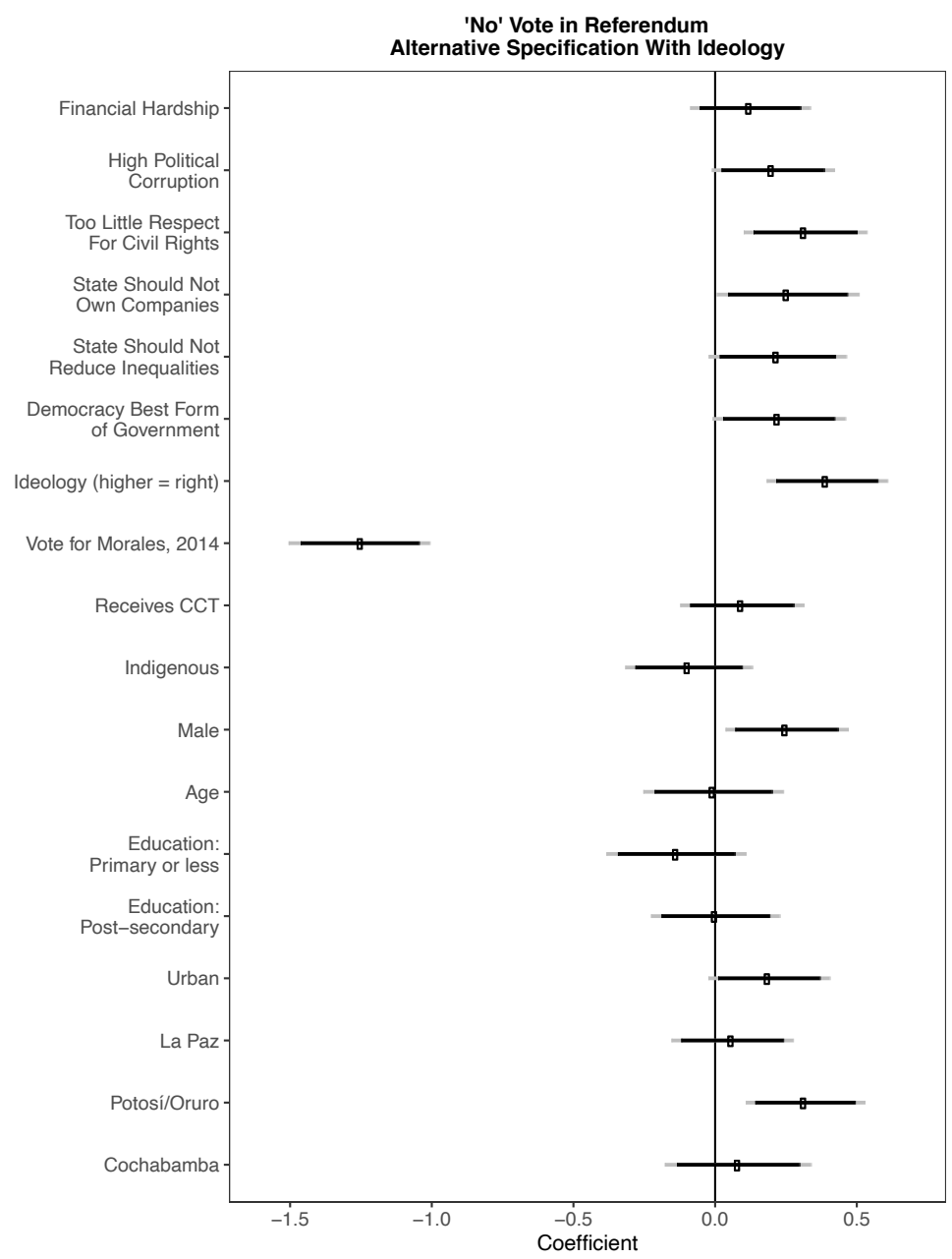

\section{Detailed variable coding}

Voting "Yes" in 2016 referendum, one of our two outcome variables, is a binary coded 1 for respondents who mention having voted "Yes" in the referendum and coded 0 for respondents who mention having voted "No". Respondents 
who do not correspond to either of those possibilities are removed from the sample.

Voting Evo Morales in 2014 election, our second outcome variable, is a binary coded 1 for respondents who mention having voted in favor of Evo Morales during the 2014 election, coded 0 otherwise. Respondents who did not participate were coded as missing values.

Financial hardship is a three-point scale interval variable coded from 1 to 3 , built from the answer given by respondents to a question asking them about the evolution of their family's income during the last two years. Respondents could mention it had "increased" (coded 1), "remained the same" (coded 2), or "decreased" (coded 3). Higher values thus indicate a worse economic situation.

High political corruption is a five-point scale interval variable built from respondents' answer to a question asking them about the proportion of their country's politicians who are involved in corruption. Respondents could answer "none" (coded 1), "less than half" (coded 2), "half" (coded 3), "more than half" (coded 4), or "all" politicians (coded 5). Higher values thus indicate higher perceptions of political corruption.

Too little respect for civil rights is a five-point scale additive variable built from respondents' answer to three distinct questions. The three questions relate to respondents' perceptions of the state of different civil rights in their country. The civil rights under consideration are press freedom, freedom of expression, and freedom of opinion. For each question, respondents could mention there is either "very little", "enough", or "too little" protection of such rights. We created a binary variable for each question indicating whether or not the respondent mentioned there is "too little" protection. After a factorial analysis indicated the questions belong to a same latent concept, the binary variables were combined to yield a four-point scale identifying respondents' level of dissatisfaction with the state of civil rights in their countries. Higher values indicate greater dissatisfaction, while smaller values indicate lower dissatisfaction.

State should not own companies is a seven-point scale interval variable built from respondents' answer to a question asking them about their level of agreement with the statement "The Bolivian state, rather than the private sector, should own the country's most important enterprises." The scale has been reversed, and runs from 0 (strongly agrees) to 6 (strongly disagrees).

State should not reduce inequalities is a seven-point scale interval variable built from respondents' answer to a question asking them about their level of agreement with the statement "The Bolivian state should implement firm policies to reduce income inequalities between the rich and the poor." The scale has been reversed, and runs from 0 (strongly agrees) to 6 (strongly disagrees).

Democracy best regime type is a seven-point scale interval variable built from respondents' answer to a question asking them about their level of agreement 
with a statement indicating that "democracy has problems, but it is the best form of government." The variable is coded from 1 to 7 , with higher values indicating greater agreement.

Ideology is a ten-point scale interval variable indicating respondents' self-placement on an ideological scale running from 1 (most left) to 10 (most right). The variable is coded from 1 to 10, with higher values indicating right-leaning self-placements.

Receives CCT is an additive four-point scale coded from 0 to 3 indicating from how many conditional cash transfer programs does the respondent's household receives money. The three programs are the Renta Dignidad, the Bono Juancito Pinto, and the Bono Juana Azurduy.

Indigenous is a dummy variable coded 1 for respondents who identified as indigenous, coded 0 otherwise.

Male is a dummy gender variable coded 1 for males and 0 for females.

Age is the actual age of respondents.

Education level: primary or less is a dummy variable coded 1 for respondents who did not reach secondary education, coded 0 otherwise.

Education level: post-secondary is a dummy variable coded 1 for respondents who completed years of schooling above the secondary level, coded 0 otherwise.

Urban is a dummy variable indicating whether the respondent was identified as living in an urban area.

La Paz is a dummy variable indicating whether the respondent was identified as residing in the La Paz department.

PotosilOruro is a dummy variable indicating whether the respondent was identified as residing in the Potosí or Oruro department.

Cochabamba is a dummy variable indicating whether the respondent was identified as residing in the Cochabamba department. 